\title{
A search for predators and food selectivity of two native species of Hydra (Cnidaria: Hydrozoa) from Brazil
}

\author{
Fernanda Cristina Massaro ${ }^{1,4}$, Natalia Felix Negreiros ${ }^{2}$ \& Odete Rocha $^{3}$ \\ ${ }^{1}$ Post Graduate Program in Environmental Engineering Science, São Carlos School of Engineering, \\ University of São Paulo - USP, Av. Trabalhador São-carlense, 400, CP 292, CEP 13560-970, São Carlos, \\ SP, Brazil. http://www.eesc.usp.br/ppgsea/ \\ ${ }^{2}$ Post Graduate Program in Ecology and Natural Resources, Department of Ecology and Evolutionary \\ Biology, Federal University of São Carlos - UFSCar, Rod. Washington Luis, Km 235, CP 676, \\ CEP 13565-905, São Carlos, SP, Brazil. http://www.ppgern.ufscar.br \\ ${ }^{3}$ Department of Ecology and Evolutionary Biology, Federal University of São Carlos - UFSCar, \\ Rod. Washington Luis, Km 235, CP 676, CEP 13565-905, São Carlos, SP, Brazil. http://www.ufscar.br \\ ${ }^{4}$ Corresponding author: Fernanda Cristina Massaro, e-mail: femassaro@gmail.com
}

MASSARO, F.C, NEGREIROS, N.F. \& ROCHA, O. A search for predators and food selectivity of two native species of Hydra (Cnidaria: Hydrozoa) from Brazil. Biota Neotrop. 13(2): http://www.biotaneotropica.org.br/ v13n2/en/abstract?article+bn00713022013

\begin{abstract}
The Hydra is the most common representative of freshwater cnidarians. In general, it is found in freshwaters on every continent, with the exception of Antarctica. The aim of the present study is to gather biological and ecological data on aspects of two species of Hydra native to Brazil: Hydra viridissima and Hydra salmacidis. Predation and food selectivity experiments were performed to assess the possible predators and the prey preferences, respectively, of the two species. The results indicate that the two species of Hydra were not consumed by any of the predators that were tested, which are typical predators of invertebrates in freshwater: nymphs of Odonata Anisoptera and the phantom midge larvae of Chaoborus sp. (Insecta), adults of Copepoda Cyclopoida (Crustacea) and the small fish Poecilia reticulata. It was observed that the smaller Hydra, $H$. viridissima, positively selected the nauplii and copepodites of calanoid copepods and small cladocerans and rejected large prey, such as the adults of calanoid copepods and ostracods. The larger $H$. salmacidis, besides the nauplii and copepodites of the calanoid copepods and small cladocerans, also positively selected the large adults of the calanoid copepods. It can be concluded that both $H$. viridissima and $H$. salmacidis are most likely preyed on little or not preyed on at all in many freshwater bodies, as they are top predators in the food chain. At the same time, they are efficient predators, and a positive relationship was observed between the prey size and the Hydra species size. Food selectivity was related to prey size as well as other prey characteristics, such as carapace thickness and swimming efficiency.
\end{abstract}

Keywords: Hydra viridissima, Hydra salmacidis, predation, prey selection, feeding.

MASSARO, F.C, NEGREIROS, N.F. \& ROCHA, O. Potenciais predadores e seletividade alimentar de duas espécies de Hydra (Cnidaria: Hydrozoa) nativas no Brasil. Biota Neotrop. 13(2): http://www.biotaneotropica. org.br/v13n2/pt/abstract?article+bn00713022013

Resumo: As hidras são os representantes mais comuns dos cnidários de água doce. Em geral, estes organismos são encontrados em todos os continentes, exceto na Antártica. O presente estudo teve como objetivo obter informações mais aprofundadas sobre aspectos biológicos e ecológicos de duas espécies de Hydra nativas no Brasil, Hydra viridissima e Hydra salmacidis. Foram realizados experimentos de predação e seletividade alimentar para se determinar, respectivamente, os potenciais predadores e as presas preferenciais destas duas espécies. Os resultados indicaram que as duas espécies de Hydra não foram consumidas por nenhum dos predadores testados, os quais são usuais predadores de invertebrados em águas doces: ninfas de Odonata e larvas de Chaoborus sp. (Insecta), adultos de Copepoda Cyclopoida (Crustacea) e peixes da espécie Poecilia reticulata. Observou-se que $H$. viridissima ao se alimentar selecionou positivamente as fases jovens de copépodos calanóides e os pequenos cladóceros, e selecionou negativamente as presas grandes, como os adultos de copépodos calanóides e os ostrácodos. Já a espécie $H$. salmacidis, a qual apresenta um tamanho maior, além de ter preferência pelos náuplios e copepoditos de copépodos calanóides e pequenos cladóceros, também selecionou positivamente os indivíduos adultos dos copépodos calanóides. Os resultados obtidos evidenciaram que as espécies $H$. viridissima e H. salmacidis provavelmente são pouco ou não são predadas em muitos ambientes naturais, sendo elas próprias os predadores de topo da cadeia alimentar nestes ambientes. Por outro lado, estes organismos são predadores eficientes e observou-se uma relação positiva entre o tamanho da espécie de Hydra e o tamanho da presa. A seletividade alimentar destas espécies esteve relacionada com o tamanho das presas, assim como com outras características, tais como a espessura da carapaça e a eficiência de natação.

Palavras-chave: Hydra viridissima, Hydra salmacidis, predação, seleção de presas, alimentação. 


\section{Introduction}

The hydra is a freshwater cnidarian, which is found attached to almost all types of hard substrate, such as macrophytes, dead leaves, stems, dead sticks and rocks (Slobodkin \& Bossert 2001). Hydras are found to occur on all continents except Antarctica (Holstein 1995). However, in Brazil there are only four known species of Hydra (Class Hydrozoa, Subclass Anthomedusae, Family Hydridae): Hydra viridissima Pallas 1766 (Cordero 1939, Wolle 1978), Hydra iheringi Cordero 1939 (Cordero 1939), Hydra intermedia Wolle 1978 (Wolle 1978), and Hydra salmacidis Silveira, Gomes \& Silva 1997 (Silveira et al. 1997). The species Hydra viridissima is also referred as Chlorohydra viridissima and thus belongs to one of the three genera (Hydra, Pelmatohydra and Chlorohydra) proposed by Schulze (1917) for the Family Hydridae. However, in recent times, few scientists have used this taxonomy and most have followed Campbell (1987) who, while recognizing four morphological groups of hydra species (viridissima, oligactis, vulgaris and braueri), kept all the species in a single genus, Hydra (Hemmrich et al. 2007, Jankowski et al. 2008, Kawaida et al. 2010). For this reason, we have called the species under study here $H$. viridissima.

The information available on freshwater cnidarians in Brazil is very limited compared with that available on freshwater cnidarians in the United States or Europe. Thus, as Silveira \& Schlenz (1999) have noted, considerable research needs to be performed on this group.

Like all cnidarians, hydras have explosive stinging structures called nematocysts, which are enclosed within epidermal cells and are abundant in the tentacles and at the oral end of the body. These structures are used for capturing prey as well as for self-protection against predators (Ruppert \& Barnes 1996). It is assumed that these nematocysts deter predators from attacking cnidarians. However, it should be noted that predation upon freshwater cnidarians has rarely been investigated. Hydras are strictly carnivorous animals and are considered to be very efficient predators (Slobodkin \& Bossert 2001). They feed mainly on crustaceans, including cladocerans and copepods, insect larvae and annelids (Pennak 1953). Cnidarians are known to feed in the following manner: (1) a prey accidentally touching an extended tentacle is captured and intoxicated by the action of nematocysts; (2) after capturing the prey, the tentacles contract toward the mouth and the mouth opens; and (3) the food in contact with the mouth is drawn into the body cavity where it is digested (Lenhoff 1968).

Ecological research on the native species of Hydra in Brazil is at a very early stage. The aim of the present study is to add to current information on the biology of the two naturally occurring species in Brazil: $H$. viridissima and $H$. salmacidis. The prey and food preferences of these species were investigated to analyse ecological questions regarding their biological interactions as prey and predator.

\section{Material and Methods}

The species $H$. viridissima is characterised by a green colour that is due to symbiosis with the chlorophycean alga Chlorella vulgaris Beijerinck 1890, which provides carbon sources to the hydra such as maltose polysaccharide (Muscatine 1965) or glucose-6-phosphate (Lenhoff \& Muscatine 1963, Roffman \& Lenhoff 1969, Kelty \& Cook 1976). H. salmacidis has no symbiosis and is characterised by a brown colour (Silveira et al. 1997).

Specimens of $H$. viridissima were swept gently from concrete tanks at the Experimental Reserve at the Federal University of São Carlos, São Carlos District, upstate São Paulo (SP), Brazil. The other species, H. salmacidis, was sampled in earth ponds at the Aquaculture Research and Training Center (CEPTA), Pirassununga District, SP, Brazil.
The medium used to culture the hydras was reconstituted freshwater, prepared as recommended by the United States Environmental Protection Agency (United... 1991) and Associação Brasileira de Normas Técnicas (Associação... 2010), described as follows: a mineral solution formulation $\left(1.5 \mathrm{~g} \mathrm{~L}^{-1} \mathrm{CaSO}_{4} \cdot 2 \mathrm{H}_{2} \mathrm{O} ; 0.2 \mathrm{~g}\right.$ $\mathrm{L}^{-1} \mathrm{KCl} ; 4.8 \mathrm{~g} \mathrm{~L}^{-1} \mathrm{NaHCO}_{3} ; 6.1 \mathrm{~g} \mathrm{~L}^{-1} \mathrm{MgSO}_{4} .7 \mathrm{H}_{2} \mathrm{O}$ in distilled water) with $40-48 \mathrm{mg} \mathrm{L}^{-1} \mathrm{CaCO}_{3}$ total hardness, a $\mathrm{pH}$ range of 7.2-7.6 and a $160 \mu \mathrm{S} \mathrm{cm}^{-1}$ conductivity.

The Hydra species were maintained separately in $200 \mathrm{~mL}$ beakers at a constant temperature of $25 \pm 2{ }^{\circ} \mathrm{C}$ with a photoperiod of $12 \mathrm{~h}$ light $/ 12 \mathrm{~h}$ dark without aeration. The specimens were fed on neonates of the cladoceran species Ceriodaphnia silvestrii Daday 1902 three times a week at a density of 10 neonates per individual per day. The water was completely changed and the culture cleaned at each feeding session.

For the experiments, predators and prey were chosen from among the items available in the water bodies from which the hydras originated. The experiments for each species were conducted separately.

To determine the possible predators of the hydras, an experiment was performed with four replicate tests and one control for each type of predator. Ten adult hydras without buds and three predators of a similar size, previously kept in starvation for $24 \mathrm{~h}$, were placed in each $200 \mathrm{~mL}$ beaker containing $150 \mathrm{~mL}$ of reconstituted water. In the control, the 10 adult hydras without buds were placed in the water alone. The following species were tested as predators: nymphs of Odonata Anisoptera (Insecta) (5.0 mm mean size), the phantom midge larvae of Chaoborus sp. (Insecta) (5.0 mm mean size) and adults of Copepoda Cyclopoida (Crustacea) (1.6 mm mean size), all of which were taken from the freshwater concrete tanks of the Experimental Reserve at the Federal University of São Carlos. The small fish Poecilia reticulata Peters 1859 (2.5 cm mean size), obtained from the long-term cultures established at the Laboratory of Ecotoxicology at the same University, was also tested as a possible predator of hydra.

The experiments were run for $24 \mathrm{~h}$ inside growth chambers with controlled temperature $\left(25 \pm 2{ }^{\circ} \mathrm{C}\right)$ and photoperiod (12 h light/12 h dark) conditions. The experimental flasks were examined every $3 \mathrm{~h}$ during the first $9 \mathrm{~h}$, and the hydras were counted to observe whether they were being consumed. If the hydras were not consumed after $9 \mathrm{~h}$, the experiment was continued for $24 \mathrm{~h}$.

A second batch of experiments was run to determine the preferred prey of Hydra spp. The following invertebrates were tested as prey: copepod nauplii, copepodites and non-ovigerous adults of Argyrodiaptomus furcatus Sars 1901 and Notodiaptomus iheringi Wright 1935 (Copepoda, Calanoida), neonates and non-ovigerous adults of $C$. silvestrii (Cladocera), and Ostracoda. The calanoid copepods and the cladocerans were obtained from laboratory cultures. The ostracods were collected from the same concrete experimental tanks from which the invertebrate predators were taken. From the same sample of the invertebrates used as prey in the experiments, 30 individuals of each species were measured or their developmental phase recorded under an optical stereomicroscope (Zeiss Stemi 2000-C) with a micrometric eyepiece. The non-parametric Kruskal-Wallis test was used to test for significant differences in size between prey species. The analysis was performed with the XLSTAT 2009 statistical package (Addinsoft 2009).

The predation experiments were performed in multi-well plates (TPP ${ }^{\circledR}$ ) with six wells of $12 \mathrm{~mL}$ capacity, where each well represented a replicate. Each experiment had four replicates and one control. Five individuals of each prey and five hydras without buds, previously starved for $24 \mathrm{~h}$, were placed in each well with $10 \mathrm{~mL}$ of reconstituted water. The control was prepared in the same way and received only the prey, without the hydras. Each experimental replicate and the control 
were observed after $5 \mathrm{~h}$ under the stereomicroscope. The remaining prey were identified and counted. During the experiments, the plates were kept in the growth chamber under controlled conditions of temperature and light.

The food selectivity coefficients were calculated from the results obtained in the experiments as the Normalised Forage Ratio - NFR (Paloheimo 1979) for each prey item and Hydra species using the Equation 1:

$$
\text { NFRi }=\left[\mathrm{r}_{\mathrm{i}} / \mathrm{p}_{\mathrm{i}}\right] / \sum_{\mathrm{i}=1}^{\mathrm{n}} \mathrm{r}_{\mathrm{i}} / \mathrm{p}_{\mathrm{i}}
$$

where NFRi $=$ normalised forage ratio; $r_{i}=$ proportion of prey of type $i$ in the consumer diet; $p_{i}=$ proportion of prey of type $i$ in the environment; and $\mathrm{n}=$ number of prey types available.

The results may indicate positive selection $\left(\mathrm{NFR}_{\mathrm{i}}>1 / \mathrm{n}\right)$ or negative selection $\left(\mathrm{NFR}_{\mathrm{i}}<1 / \mathrm{n}\right)$. When $\mathrm{NFR}_{\mathrm{i}}=1 / \mathrm{n}$, there is no selection, that is, the food item is consumed in the same proportion as it is available in the environment.

\section{Results}

In the experiments performed to determine the potential predator species of $H$. viridissima and $H$. salmacidis, no hydras were consumed during the initial $9 \mathrm{~h}$. Therefore, the experiments were prolonged to $24 \mathrm{~h}$. After this period, it was again observed that there was no

Table 1. Mean length ( $\mathrm{mm}$ ) and size classes of prey items used in the food selectivity experiments. The classes were compared for significant differences in size by the non-parametric Kruskal-Wallis test $(p<0.05)$.

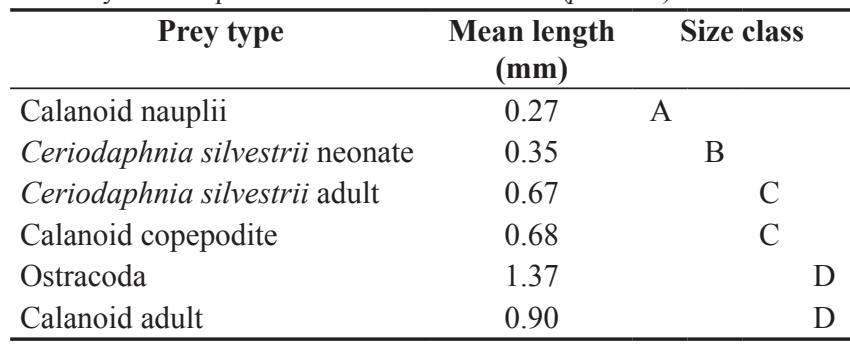

Different capital letters denote size classes that are significantly different $(p<0.05)$.

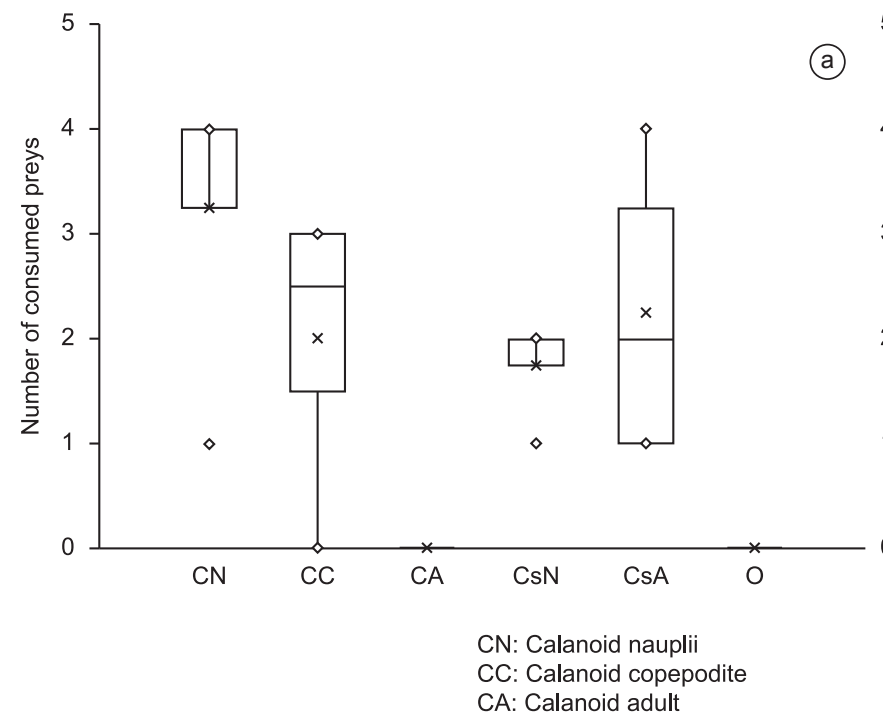

predation of hydras by any of the possible predator species. Thus, it can be concluded that Odonata Anisoptera, the phantom midge Chaoborus sp., the adults of Copepoda Cyclopoida and the fish $P$. reticulata, which were tested as predators in the present study, do not consume hydras in freshwater.

In the experiments performed to determine the food selectivity, the prey species used represented four size classes, which were significantly different (Kruskal-Wallis, $p<0.05$ ). Here, the calanoid nauplii were the smallest and the adult calanoid copepods and ostracods were the largest, as shown in Table 1.

The results of the food selectivity experiments for both species of Hydra are shown in Figure 1. It can be observed that after $5 \mathrm{~h}$, $H$. viridissima consumed a large number of calanoid nauplii, followed by the adults of the small $C$. silvestrii, calanoid copepodites, and neonates of $C$. silvestrii. The calanoid adults and ostracods were not consumed in any way during the experimental period. However, for $H$. salmacidis, the most frequently consumed food item was calanoid adults, and all these organisms were preyed in all replicates. In decreasing order of consumption, these were followed by the nauplii and copepodites of the calanoid copepods, adults of the cladoceran $C$. silvestri, and the neonates of $C$. silvestrii. Only one Ostracoda individual was consumed in one replicate. No prey individuals were lost in the controls.

The NFR coefficients calculated from the number of prey consumed by $H$. viridissima and $H$. salmacidis are presented in Figures 2 and 3, respectively. It can be observed that $H$. viridissima showed positive selection for calanoid copepod nauplii in all replicates, for adults of $C$. silvestrii and copepodites of calanoid copepods in three replicates, and for neonates of $C$. silvestrii in two replicates. In all replicates, there was negative selection for calanoid copepod adults and ostracods. For H. salmacidis, however, the results confirmed that there was positive selection for calanoid copepod adults in all replicates, for nauplii and copepodites of calanoid copepods and adults of $C$. silvestrii in three replicates, and for neonates of $C$. silvestrii in only one replicate. In all replicates, there was negative selection for the ostracods.

\section{Discussion}

In all experiments performed to search for the possible natural predators of the two species of Hydra under study, no predation was

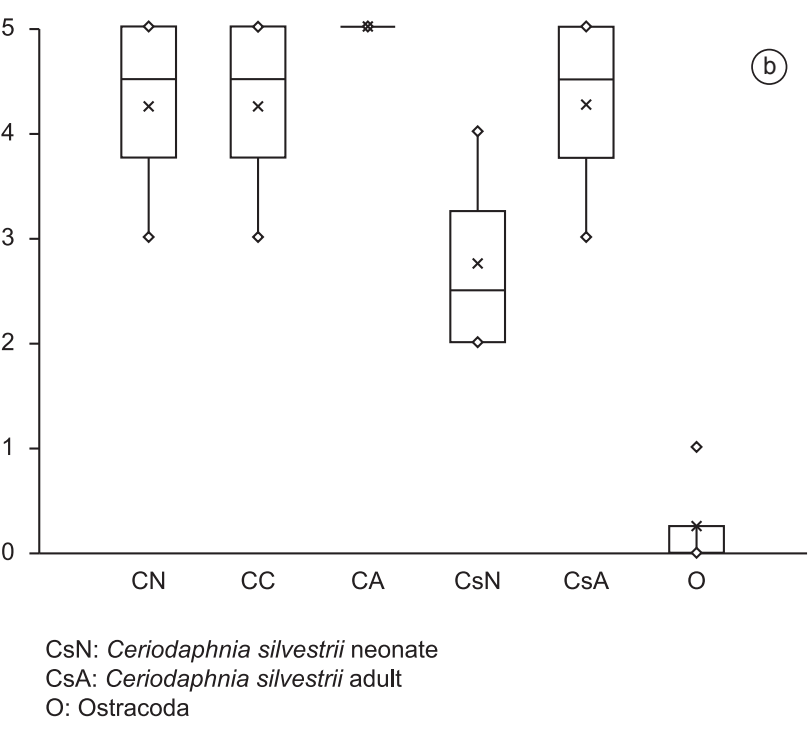

Figure 1. Mean number of individuals of each prey item consumed by (a) Hydra viridissima and (b) Hydra salmacidis in the food selectivity experiments after $5 \mathrm{~h}$ exposure. 
observed by the local invertebrates that are well-known freshwater predators. According to Slobodkin \& Bossert (2001), few predators are found to attack cnidarians due to their nematocysts, which make them unpalatable.

Tortoises, fish, crabs, echinoderms, and platyhelminthes are some of the known predators of marine cnidarians. However, predation on freshwater cnidarians has been less well researched until now (Slobodkin \& Bossert 2001). It is known that crayfish feed on the freshwater medusa Craspedacusta sp. (Dodson \& Cooper 1983). It has also been reported that hydras are preyed by platyelminthes (Hyman 1940, Kanaev 1969), despite the observation that small platyhelminths avoid contact with these cnidarians (Slobodkin \& Bossert 2001).

Cuker \& Mozley (1981) observed that the fishes Salvelinus namaycush Walbaum 1792, Thymallus arcticus Pallas 1776, and Cottus cognatus Richardson 1836 did not consume the arctic species

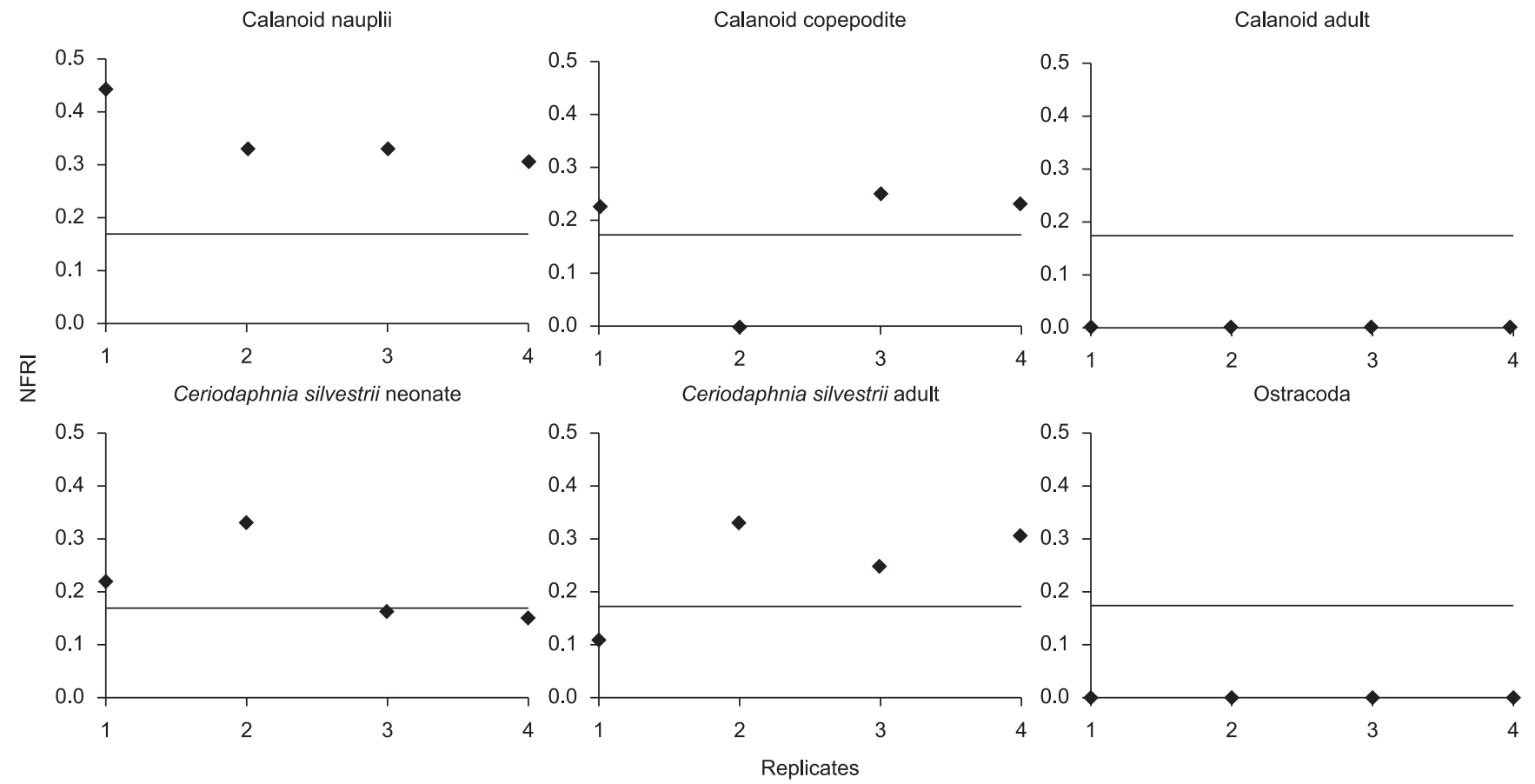

Figure 2. Food selectivity coefficients (Normalised Forage Ratio - NFR) for each food item consumed by Hydra viridissima. The line represents the reference value above which there is positive selection (Paloheimo 1979).

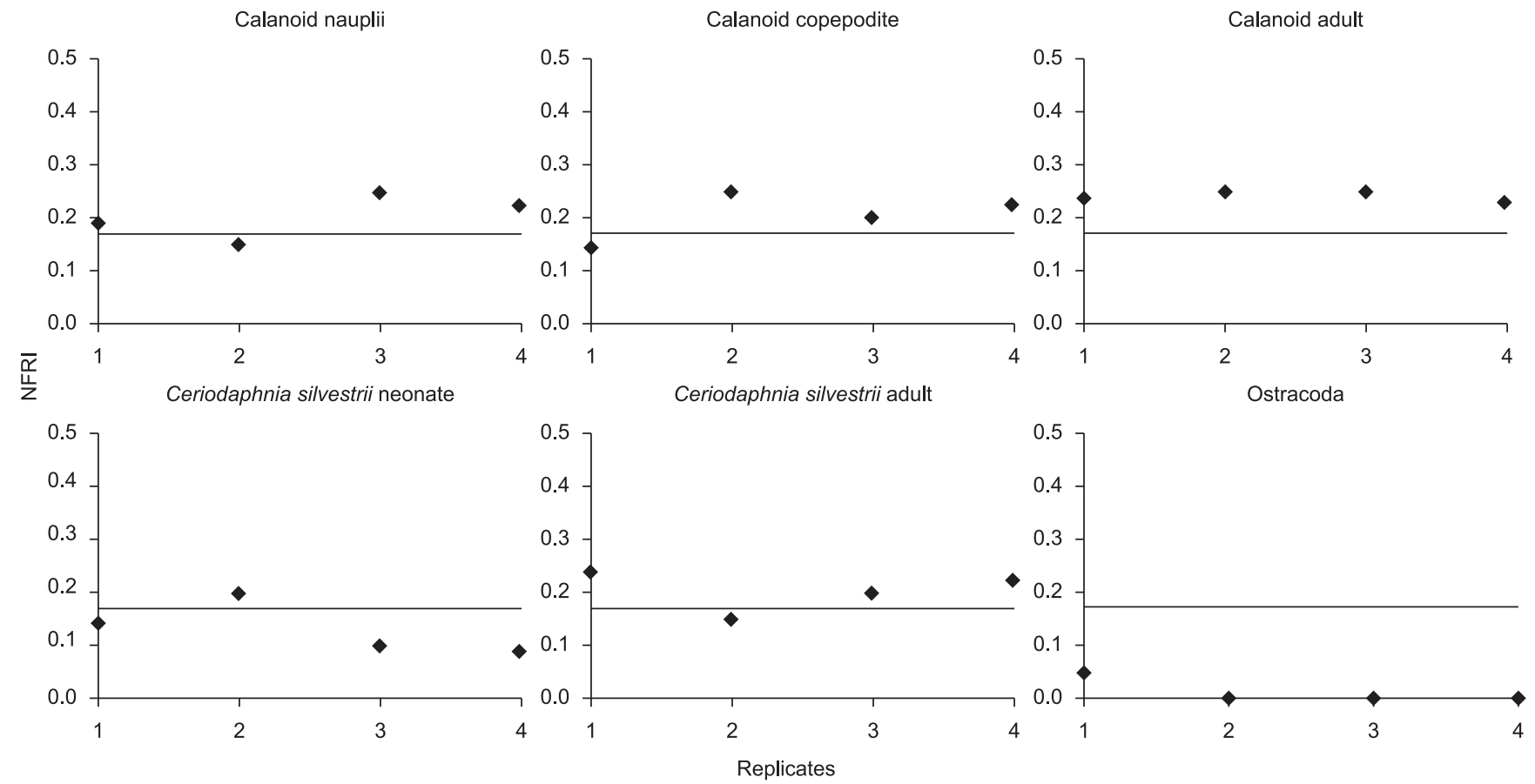

Figure 3. Food selectivity coefficients (Normalised Forage Ratio - NFR) for each food item consumed by Hydra salmacidis. The line represents the reference value above which there is positive selection (Paloheimo 1979). 
Hydra cf. canadensis Rowan 1930. In addition, they tested whether the gastropods Valvata sp. and Lymnaea sp. preyed on hydras. The results demonstrated that Lymnaea consumed the cnidarians, but only when no other food was available to them. Further, it was observed that starved snails accepted the hydra more readily than well-fed ones. It was apparent that the gastropods covered the hydras with mucus, thereby protecting themselves from the nematocysts.

Therefore, the presence of nematocysts most likely prevented the consumption of hydras in the present study. Another fact to be considered is that hydras are typically immobile when attached to a substrate. However, they can move by protruding, contracting or curving their body column and tentacles, can detach themselves and can change place by jumping or floating (Ruppert \& Barnes 1996). It was observed that in these experiments the $H$. viridissima and $H$. salmacidis individuals either remained attached to the wall of the test recipient or floated in the water.

Prey movements or the absence of movement can significantly affect capture by predators (Wright \& O'Brien 1982). Most predators tested in the present study have been found to depend on visual or tactile stimuli to detect their prey. Thus, it can be assumed that the low mobility of hydras may have contributed to their not being detected and captured.

However, hydras are considered to be extremely efficient predators (Slobodkin \& Bossert 2001). In the present study, it was observed that the species $H$. viridissima consumed the young developmental phases of copepods (nauplii and copepodites) and small cladocerans but did not consume the larger prey (adult calanoid copepods and ostracods). However, H. salmacidis consumed prey of all sizes.

In general, larger preys have a greater chance of escaping predation from hydras, even after contact with the nematocysts (Slobodkin \& Bossert 2001). Hershey \& Dodson (1987) observed that the larger larvae of the chironomid Cricotopus bicinctus Meigen 1818 were less susceptible to predation by Hydra sp. Cuker \& Mozley (1981) observed that the species $H$. cf. canadensis preferred to consume small prey, such as species of Cyclops and Bosmina.

Some factors, such as carapace hardness and swimming efficiency, are known to affect the ability of the prey to escape from Hydra predation (Cuker \& Mozley 1981, Schwartz et al. 1983). In a study performed by Schwartz et al. (1983), it was observed that the cladocerans Scapholeberis kingi Sars 1888 and Simocephalus vetulus Müller 1776 were immune to the predation of Hydra oligactis Pallas 1766 and Hydra pseudoligactis Hyman 1931 (accepted as $H$. canadensis Rowan 1930). According to the authors, this was most likely because the above-mentioned cladoceran species have an exoskeleton of sufficient thickness to prevent the penetration of nematocysts and/or provide immunity to the toxin released by this structure. In addition, their swimming patterns increased their chance of escape. Some ostracods are also protected from hydra predation by the hardness of their carapace (Slobodkin \& Bossert 2001).

Another factor influencing prey capture is the size of the hydras (Slobodkin et al. 1991). The species H. viridissima can reach $5.0 \mathrm{~mm}$ in length, and its tentacles are generally shorter than its body column (Wolle 1978), whereas H. salmacidis can reach a length of almost $13.0 \mathrm{~mm}$ and has tentacles three times as long as its body column (Silveira et al. 1997).

Thus, the present study shows that $H$. viridissima could not consume the adults of calanoid copepods or the ostracods due to factors such as the size of the hydra, the size and swimming efficiency of the adult calanoid copepods and the hard carapace of the ostracods. However, because of its larger size, $H$. salmacidis could easily capture the adults of calanoid copepods, which were the prey consumed most by this hydra, whereas the hard carapace of the ostracods protected them against predation.

Furthermore, H. salmacidis consumed a larger quantity of prey than $H$. viridissima, which is clearly related to its size, but could also be a consequence of the symbiosis of the latter with the photosynthetic C. vulgaris. According to Slobodkin \& Bossert (2001), a green hydra needs only one or two nauplii of Artemia salina Linnaeus 1758 per day to start developing a bud, whereas a brown hydra needs 5-10 nauplii per day. Cuker \& Mozley (1981) found up to 23 carapaces in the cavity of $H$. cf. canadensis, which reached a maximum size of $20.0 \mathrm{~mm}$ and had tentacles measuring up to five times as long as the body column. Lasker et al. (1982) reported that $H$. viridissima, which is considerably smaller, could reach only a maximum of 5-7 nauplii of $A$. salina in its gastro-vascular cavity.

Based on the results obtained in the present study, it can be concluded that both $H$. viridissima and $H$. salmacidis are likely top predators in their own habitats, as they are protected from predators by toxins released by the nematocysts as well as their low mobility. Regarding the feeding pattern of these species, it should be mentioned that they exhibited both positive and negative selectivity and that they select their prey on the basis of its size as well as other characteristics, such as carapace thickness and swimming efficiency.

\section{Acknowledgments}

We would like to thank the Brazilian Research Council (CNPq) for their financial support, D.T. Okumura and R.M. dos Santos for supplying prey items, and T.C. Roberts for the English version of the manuscript.

\section{References}

ASSOCIAÇÃO BRASILEIRA DE NORMAS TÉCNICAS - ABNT. 2010. NBR 13373: Ecotoxicologia aquática - Toxicidade crônica - Método de ensaio com Ceriodaphnia spp (Cladocera, Crustacea). ABNT.

ADDINSOFT. 2009. XLSTAT 2009 version 11.4.

CAMPBELL, R.D. 1987. A new species of Hydra (Cnidaria: Hydrozoa) from North America with comments on species clusters within the genus. Zool. J. Linn. Soc-Lond. 91:253-263. http://dx.doi. org/10.1111/j.1096-3642.1987.tb01510a.x

CORDERO, E.H. 1939. Observaciones sobre algunas especies SudAmericanas del género Hydra. I. Hydra en el Nordeste del Brazil. An. Acad. Bras. Cienc. 11(4):335-340.

CUKER, B.E. \& MOZLEY, S.C. 1981. Summer population fluctuations, feeding, and growth of Hydra in an arctic lake. Limnol. Oceanogr. 26(4):697-708. http://dx.doi.org/10.4319/lo.1981.26.4.0697

DODSON, S.I. \& COOPER, S.D. 1983. Trophic relationships of the freshwater jellyfish Craspedacusta sowerbii Lankester 1880. Limnol. Oceanogr. 28:345-351. http://dx.doi.org/10.4319/1o.1983.28.2.0345

HEMMRICH, G., ANOKHIN, B., ZACHARIAS, H. \& BOSCH, T.C.G. 2007. Molecular phylogenetics in Hydra, a classical model in evolutionary developmental biology. Mol. Phylogenet. Evol. 44:281-290. http://dx.doi. org/10.1016/j.ympev.2006.10.031

HERSHEY, A.E. \& DODSON, S.I. 1987. Predator avoidance by Cricotopus: cyclomorphosis and the importance of being big and hairy. Ecology. 68(4):913-920. http://dx.doi.org/10.2307/1938362

HOLSTEIN, T. 1995. Cnidaria: Hydrozoa. In Süsswasserfauna von Mitteleuropa (A. Brauer, J. Schwoerbel \& P. Zwick, eds.). Gustav Fisher Verlag, Stuttgart, p.1-110.

HYMAN, L.H. 1940. The invertebrates: Protozoa through Ctenophora. McGraw-Hill, New York.

JANKOWSKI, T., COLLINS, A.G. \& CAMPBELL, R. 2008. Global diversity of inland water cnidarians. Hydrobiologia 595:35-40. http://dx.doi. org/10.1007/s10750-007-9001-9 
KANAEV, I.I. 1969. Hydra: essays on the biology of freshwater polyps. Soviet Academy of Science, Moscow.

KAWAIDA, H., SHIMIZU, H., FUJISAWA, T., TACHIDA, H. \& KOBAYAKAWA, Y. 2010. Molecular phylogenetic study in genus Hydra. Gene. 468:30-40. http://dx.doi.org/10.1016/j.gene.2010.08.002

KELTY, M.O. \& COOK, C.B. 1976. Survival during starvation of symbiotic, aposymbiotic, and non-symbiotic Hydra. In Coelenterate ecology and behavior (G.O. Mackie, ed.). Plenum Press, New York, p.409-414.

LASKER, H.R., SYRON, J.A. \& CLAYTON JUNIOR, W.S. 1982. The feeding response of Hydra viridis: effects of prey density on capture rates. Biol. Bull. 162:290-298. http://dx.doi.org/10.2307/1540984

LENHOFF, H.M. 1968. Behavior, Hormones, and Hydra. Science 161(3840):434-442. http://dx.doi.org/10.1126/ science.161.3840.434

LENHOFF, H.M. \& MUSCATINE, L. 1963. On the role of algae symbiotic with Hydra. Science 142:956-958. http://dx.doi.org/10.1126/ science.142.3594.956

MUSCATINE, L. 1965. Symbiosis of Hydra and algae. III Extracellular products of the algae. Comp. Biochem. Physiol. 16:77-92. http://dx.doi. org/10.1016/0010-406X(65)90165-9

PALOHEIMO, J.E. 1979. Indices of food type preference by a predator. J. Fish. Res. Board Can. 36:470-473. http://dx.doi.org/10.1139/f79-066

PENNAK, R.W. 1953. Freshwater Invertebrates of the United States. The Ronald Press Company, New York.

ROFFMAN, B. \& LENHOFF, H.M. 1969. Formation of polysaccharides by Hydra from substrates produced by their endosymbiotic algae. Nature 221:381-382. http://dx.doi.org/10.1038/221381a0

RUPPERT, E.E. \& BARNES, R.D. 1996. Zoologia dos invertebrados. Roca Ltda, São Paulo.
SCHULZE, P. 1917. Neue Beiträge zu einer Monographie der Gattung Hydra. Arch. Biontol. 4:29-119.

SCHWARTZ, S.S., HANN, B.J. \& HEBERT, P.D.N. 1983. The feeding ecology of Hydra and possible implications in the structuring of pond zooplankton communities. Biol. Bull. 164:136-142. http://dx.doi. org/10.2307/1541196

SILVEIRA, F.L., GOMES, C.S. \& SILVA, Z.S. 1997. New species of Hydra Linnaeus, 1758 (Cnidaria, Hydrozoa) from southeastern Brazil. Bol. Mus. Nac., Zool. 373:1-15.

SILVEIRA, F.L. \& SCHLENZ, E. 1999. Cnidários. In Invertebrados de água doce (D. Ismael, W.C. Valentini, T. Matsumura-Tundisi \& O. Rocha, eds.). Fundação de Amparo à Pesquisa do Estado de São Paulo, São Paulo, p.13-15.

SLOBODKIN, L.B., BOSSERT, P., MATESSI, C. \& GATTO, M. 1991. A review of some physiological and evolutionary aspects of body size and bud size of Hydra. Hydrobiologia. 216-217:377-382. http://dx.doi. org/10.1007/BF00026489

SLOBODKIN, L.B. \& BOSSERT, P.E. 2001. Cnidaria. In Ecology and classification of North American freshwater invertebrates (J.H. Thorp \& A.P. Covich, eds.). Academic Press, p.135-154. http://dx.doi.org/10.1016/ B978-012690647-9/50006-5

WOLLE, L.C. 1978. Hydra intermedia sp. nov. and notes on Chlorohydra viridissima (Pallas) (Cnidaria). Bol. Zool., USP. 3:143-152.

WRIGHT, D.I. \& O'BRIEN, W.J. 1982. Differential location of Chaoborus larvae and Daphnia by fish: the importance of motion and visible size. Am. Midl. Nat. 108(1):68-73. http://dx.doi.org/10.2307/2425293

UNITED STATES ENVIRONMENTAL PROTECTION AGENCY - USEPA. 1991. USEPA/600/4-90/027 Methods for measuring the acute toxicity of effluents and receiving waters to freshwater and marine organisms. Ohio, Cincinnati. 